in Science

through time and space
Жамият ва инновациялар-

Общество и инновации -

Society and innovations

Journal home page:

https://inscience.uz/index.php/socinov/index

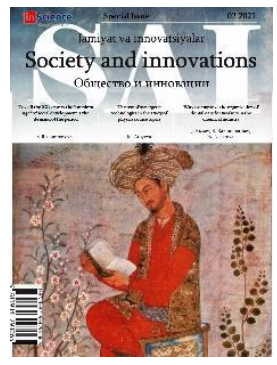

\title{
Technology for the development of career-oriented textbooks in foreign languages for students of humanities
}

\section{Farogat MUHAMMEDOVA ${ }^{1}$}

Gulistan State University

\section{ARTICLE INFO}

\section{Article history:}

Received January2021

Received in revised form

15 January 2021

Accepted 20February 2021

Available online

7 March2021

\section{Keywords:}

Pedagogy

Psychology

Linguistic

Educational methods

Communicativeness

Foreign language

\begin{abstract}
One of the features of the design of the educational process in the context of the competence-based approach is that the detailed nomenclature of competencies is not fully regulated by the standard. The composition of competencies reflected in the general educational program of a particular university depends on the specifics of the university, its positioning and status and is determined based on the requirements imposed by the practice of professional activity of graduates. In these conditions, there is a need for professionally oriented teaching aids in a foreign language, which are built on the basis of the competence model of a graduate of a particular university and the content of which is developed taking into account the specifics of the content of a student's training in this educational institution
\end{abstract}

2181-1415/C 2021 in ScienceLLC.

This is an open access article under the Attribution 4.0 International (CC BY 4.0) license (https://creativecommons.org/licenses/by/4.0/deed.ru)

\section{Gumanitar ta'lim yo'nalishlari talabalari uchun xorijiy til bo'yicha kasbga yo'naltirilgan o'quv qo'llanmani ishlab chiqish texnologiyasi}

Калит сузлар:
Pedagogika
Psixologiya
Lingvistika
Ta'lim metodlari
Kommunikativlik
Chet tili.

Калит сўзлар:

Ta'lim metodlari

Chet tili.

\section{АННОТАЦИЯ}

Kompetentlikka asoslangan yondashuv sharoitida ta'lim jarayonini loyihalashning o'ziga xos xususiyatlaridan biri shundaki, Kompetentsiyalarning batafsil nomenklaturasi standart bilan to'liq tartibga solinmaydi. Muayyan universitetning umumiy ta'lim dasturida aks etgan kompetensiyalar tarkibi universitetning o'ziga xos xususiyatlari,

\footnotetext{
${ }^{1}$ Lecturer Gulistan State University, Gulistan, Uzbekistan

E-mail: Muxammedovafarogat1971@Gmail.Com
} 
uning joylashuvi va holatiga bog'liq bo'lib, bitiruvchilarning kasbiy faoliyati amaliyoti tomonidan qo'yiladigan talablardan kelib chiqqan holda belgilanadi. Bunday sharoitda muayyan universitet bitiruvchisining kompetentlik modeli va mazmuni asosida qurilgan chet tilida kasbiy yo'naltirilgan o'quv qo'llanmalariga ehtiyoj mavjud bo'lib, bu ta'lim muassasasida talabalarning ta'lim mazmunining o'ziga xos xususiyatlarini hisobga olgan holda ishlab chiqiladi

\section{Технология разработки профориентационных учебников по иностранным языкам для студентов гуманитарных специальностей}

Ключевые слова:

Педагогика

Психология

Лингвистика

Методы обучения

Коммуникативность

Иностранный язык
АННОТАЦИЯ

Одной из особенностей проектирования
образовательного процесса в контексте компетентностного подхода является то, что детальная номенклатура компетенций не в полной мере регламентирована стандартом. Состав компетенций, отраженных в общеобразовательной программе конкретного вуза, зависит от специфики вуза, его позиционирования и статуса и определяется исходя из требований, предъявляемых практикой профессиональной деятельности выпускников. В этих условиях возникает потребность в профессионально ориентированных учебных пособиях по иностранному языку, которые строятся на основе компетентностной модели выпускника конкретного вуза и содержание которых разрабатывается с учетом специфики содержания подготовки студента в данном образовательном учреждении

Currently, foreign language communicative competence is assigned an increasingly significant role in the graduates.

In connection with the development of international business, political, cultural ties, the requirements for the level of foreign language training of university graduates have increased significantly.

It must be admitted that the creation of educational materials that meet modern requirements is the most difficult task for their author. In modern conditions, the lifespan of a textbook developed for students of a certain specialty cannot be very long. The educational material is developed on the basis of authentic texts that contain factual information reflecting the current situation in a particular area of public life. This data is quickly outdated. In addition, the area of interest of students may change. The problems that are being actively discussed today will fade into the background in a few years. This leads to the need to revise topics, situations, texts, lexical content of the educational material[1]. 
Thus, the need to develop textbooks in line with the above-mentioned trends in the development of higher education, as well as the importance of prompt updating of textbooks, taking into account the changes taking place in specialized fields of knowledge, requires finding ways to increase the efficiency of both the textbooks themselves and the process of their creation.

As the analysis of the literature has shown, by now the problems of the didactic foundations of the textbook have been relatively solved, including the justification of its functions in the educational process, its connection with other components of the training system, methods for assessing the effectiveness of the textbook have been determined. These problems were investigated in the 70s - 80s of the last century by such scientists as I.D. Zverev, V.V. Kraevsky, I. Ya. Lerner, I.L.Bim, M.N. Vyatutnev, A.R. Arutyunov and others. However, the authors mainly turned to the questions of the school textbook. Problems of educational and methodological support of language education at the university remained outside the attention of scientists[2].

It should also be noted that a lot of time has passed since the publication of the above authors. During this period, there have been changes in the target settings of language education, the theory of teaching a foreign language has passed a certain way in its development. It has become generally recognized that it is necessary to provide an individual educational trajectory for each student with the help of a single textbook or study guide, to purposefully form his educational competencies. In addition, issues related to the specifics of creating a textbook aimed at performing a narrow range of professionally oriented learning tasks were not considered[3]. It should also be noted that updating and republishing the textbook is associated with significant time and material costs. Therefore, at present, such a textbook can be considered effective, in which the possibility of development is laid, that is, the attraction of new topics, problems, techniques and forms of work in the course of the educational process without the need to republish the textbook.

All of the above gives reason to believe that the theory of creating a textbook, developed at the end of the last century, needs significant additions, taking into account modern trends in the development of educational literature and based on modern approaches to building the learning process[4].

In recent years, a number of works have been published on practical issues related to the There is a number of modern studies devoted to professionally oriented teaching of a foreign languages.

The studies of these authors are aimed at developing approaches to building an educational process focused on the formation of professional foreign language communicative and educational competencies. The principles of professional linguo didactics, approaches to determining the content of professionally oriented education, methods and forms of educational activity are discussed in detail. At the same time, the issues of constructing educational materials were not properly covered[5].

In the methodology of professionally oriented teaching of a foreign language and didactics of higher education, there is a relatively small number of studies entirely devoted to the improvement of educational and methodological support of the educational process However, a number of issues were not covered in sufficient detail. Thus, an essential problem is the integration of textbooks designed to solve a limited number of particular 
learning problems and having a professional orientation, with already used textbooks and teaching aids.

Insufficient attention in the works is paid to the implementation of the principle of accessibility and feasibility in conditions when the focus of the learning process on the formation of competencies leads to the complication of the educational material. In addition, the development of communication tasks, which objectively presents a significant difficulty for teachers, requires the use of a holistic system of methods of work on preparing a manual, covering the entire process of its creation - from the stages of determining the initial data and planning the concept of the manual to the stage of assessing its effectiveness.

As practice shows, existing textbooks in a foreign language do not always correspond to the latest achievements pedagogy, psychology, methods of teaching a professionally oriented foreign language. A number of contradictions have emerged between the modern requirements for educational and methodological support of the educational process and approaches to the construction of the content of textbooks, implemented in practice[9].

1. The contradiction between the activity-oriented nature of the learning objectives determined by foreign language programs and the approach to the development of tasks implemented in the teaching materials, which does not allow reaching such a level of development of communicative competence, which is necessary for the creative use of a foreign language in combination with professional knowledge and skills to solve new tasks. Existing textbooks rarely contain tasks focused on the use of a foreign language as a means of achieving non-linguistic goals. At the same time, there are textbooks in which communicative teaching methods are used that are focused on professional topics, but at the same time do not take into account the need to develop specific skills of speech and intellectual activity related to the specialty.

2. The contradiction between the requirement for the formation of emotional-value, personal components of competencies, the development of the ability for professional reflection, effective social interaction and insufficiently developed approaches to the creation of educational materials that allow using these aspects of the activity in the educational process.

3. The contradiction between the need to ensure the professional orientation of training, which leads to the complication of the teaching materials used, and the requirement of accessibility and feasibility of the training content.

4. The contradiction between the tendency towards a narrow professional orientation of the content of textbooks, due to the requirement the connection between the content of the learning process and the future profession of students, and the need to develop universal foreign language skills, adaptable to various contexts of activity, to ensure the required professional mobility of university graduates.

5. The contradiction between the requirement to achieve learning goals in the most optimal way while minimizing the cost of training time and the insufficient development of practical recommendations regarding the selection and organization of the content of teaching aids, allowing to effectively solve particular learning problems.

Thus, research is currently relevant, in which the substantiation of the theoretical foundations of the creation of textbooks is combined with practical recommendations for their implementation. Practical recommendations should be formulated in the form of an 
integral system of methods and selection criteria, organization of educational material, methods of developing tasks, conditions for implementing principles corresponding to the modern scientific paradigm, which allows us to talk about the relevance of the selected problem.

The problem of the research is the definition and substantiation of a model for the development of a textbook, with the help of which it is possible to overcome the indicated contradictions and provide the required level of training of students in a foreign language[10].

The object of the research is the process of developing teaching aids for professionally oriented teaching of a foreign language to university students.

The subject of the research is the technology of developing textbooks for professionally oriented teaching of a foreign language to students of humanitarian specialties, that is, mechanisms, methods, techniques, an algorithm for their creation.

The purpose of the study is to develop, theoretically substantiate and experimentally test the technology for creating a textbook for professionally oriented teaching of a foreign language to students of humanitarian specialties.

\section{LIST OF REFERENCES:}

1. Azimov E. G., Shchukin A. N. Dictionary of methodological terms (theory and language teaching practice). - SPb .: Zlatoust, 1999 .-- 472 p.

2. Azimov E. G., Shchukin A. N. New dictionary of methodological terms and concepts (theory and practice of teaching languages). - M .: Publishing house IKAR, 2009. -448 p.

3. Aitov VF About the levels of problematicity of training tasks at mastering a foreign language at non-linguistic faculties of pedagogical universities // Izvestiya Rossiiskogo gos. pedagogical. un-ta them. A.I. Herzen. - 2006. -№ 7 (17): Psychological and pedagogical sciences (pedagogy, psychology, theory and teaching methods). - S. 127-136.

4. Alekseeva L.E. Optimization of the process of teaching a foreign language professionally oriented communication of students of the Faculty of International Relations: on the material of the English language: dis.... Cand. pedagogical. sciences. - SPb., 2002 .-- 313 p.

5. Alekseeva L.E. Methodology of teaching professionally oriented foreign language. Course of lectures: Methodical. allowance. - SPb .: Philological Faculty of Saint Petersburg State University, 2007 .-- 136 p.

6. Alekseeva L.E. Development of teaching materials in teaching professionally oriented foreign language // Homo Loquence: topical issues of linguistics and methods of teaching foreign languages: Sat. scientific. Art. Issue 4. / Ed. I. Yu. Schemeleva; St. Petersburg branch of the National issled. University "Higher School of Economics". - SPb .: Department of Operational Printing of the National Research University Higher School of Economics - SPb, -2012, -S. 303-313.

7. Antonova S. G., Tyurina JI. D. Modern study book: creation educational literature of a new generation. - $M$.: Agency "Publishing service", 2001.-288 p.

8. Antonova S. G., Tyurina JI. D. Theory and problems of publishing educational literature of a new generation. - M .: Research Center for the Problems of the Quality of Training of Specialists, 2002. - 76 p. 
9. Antsiferova O.V. Communicative speech situation as the basis for development speaking skills in teaching RFL: 1 certification level: dis. ... Cand. pedagogical sciences. SPb., 2005 .- 241 p.

10. Ariyan M.A. Mechanisms and conditions of social development of students by means of a foreign language // Higher education in Russia. - 2011. -№ 5. - S. 124-128. 